\title{
Almanac: Affective method
}

\section{Tara Mehrabi}

Karlstad University

DOI: https://doi.org/ 10.1344/jnmr.v1i2.31973

Affective method (AM) is often discussed in relation to the affective turn, new materialism, and in particular the study of material-discursive and "affective processes in relation to a certain empirical study" (Knudsen \& Stage, 2015, p.1). AM takes affective encounters and bodily responses as a crucial part of knowledge production; one that can formulate new questions, research agendas, and modes of data collection and analyses (Knudsen \& Stage, 2015). Affective methodology takes emotions and bodily affects such as love, disgust, intensity and desire seriously because such responses and resonances expose ethical dilemmas that are part of knowledge production processes, while simultaneously offering other modes of ethics (Mehrabi, 2018;2016). Such methodologies are particularly essential for inclusion within the context of science and technology, which are often understood to be objective, disembodied and value free.

AM highlights the embodied reality of doing science "affectively". Anthropologist of science Natasha Myers suggests that doing laboratory work requires technicians to "get entangled - kinesthetically and affectively - in their modelling efforts" (2015, p. 1; italics in the original). She writes, molecular biology and protein modeling require technicians to "engage their bodies actively in their work" $(2015$, p. 1). She calls it the "kinesthetic" of practicing molecular biology which refers to "the visceral sensibilities, movements, and muscular knowledge that modelers bring to their body experiments". Myers defines affect as "the energetics, intensities, and emotions that propagate through" laboratory work (2015). She understands both the kinesthetic and affective realities of doing laboratory work as "feeling"; the former highlights the feeling of the organism and the latter refers to the feeling for the organism (Keller, 1983; Holmberg, 2011).

Staying with such affective moments of knowledge production is essential because it enables writing about ethics of human and nonhuman/nature/animal encounters within sciences differently. Such forms of writing are particularly important when concerning 
nonhumans that trigger fear such as ticks, flies, viruses, etc. This is because it highlights the reciprocal modes of doing science in which animals are not passive recipients but active agents in the process of knowledge production. It emphasizes the embodied realities of doing science, moving away from the myth of absolute objectivity and disembodied science. Scientists must become hospitable, habituated to, care for, embody, and even become something else with the abject to be able to do science as the subject and object. In turn, scientist and the abject "intra-animate" one another in the dance of doing science (Myers, 2010). But mostly it brings to the fore how particular bodies (those that trigger fear, discomfort or abjection) become the most disposable and killable forms of life in the science economy.

As Sara Ahmed (2014) argues, feelings such as disgust are closely linked to social abjection; rooted in cultural phenomena associated historically with particular bodies. Moreover, such feelings are not something abstract that happens inside a subject but they are affective performative bodily realities that happen in between bodies and through close encounters. Those feelings do things, materializing realities in different ways. Inspired by Ahmed among others, Jacob Bull (2014) writes about ticks, discussing the possibilities for an ethical response to negatively loaded encounters that are suffused with feelings such as disgust, fear and repulsion rather than love and compassion. He identifies a limit within accounts of multispecies ethics or ethics of relationality. These accounts tend to be limited to the scope of animals with which humans have close relations such as domestic animals, "companion species" (Haraway, 2008), animals on which we rely as food resources and sometimes laboratory mammals, such as apes and mice. Recent works within new materialism have been successful in addressing this disjunction (Bates \& Schlipalius, 2013; Hird, 2009). New materialist scholars argue that, staying with negative emotions, attending to such dynamic affective encounters, bodily responses and material affinities with the abject other is crucial for understanding "humananimal interaction" from a non-anthropocentric point of view.

To sum up, affective method enables an ethical mode of doing research that takes its point of departure in situated relations and material-discursive intra-actions rather than the pre-established categories and hierarchical binaries. It prevents scientific positivism everting its narratives and logic of sacrifice and the greater good, while simultaneously resisting cultural relativism. Instead, it takes its point of departure in the material, cultural, 
social, embodied intensities and everchanging dynamics that are the constitutive part of science in the laboratory.

[Parts of the above text is published in: Mehrabi, Tara. 2018. Being intimate with flies: on affective methodologies and laboratory work. Women, Gender \& Research. 27(1), 73-80.]

\section{HTTPS://KOENSFORSKNING.SOC.KU.DK/ENGLISH/KKOF/ HTTPS://TIDSSKRIFT.DK/KKF/INDEX}

GENEALOGIES: Sara Ahmed, Clare Hemmings, Natasha Myers, Britta T. Knudsen and Carsten Stage.

SYNONYMS: Embodied and situated method, knowing through bodily intensities and material-discursive encounters, doing science/research differently

ANTONYMS: positivist method, objectivity, disembodied science, cultural relativism

\section{Bibliography}

Ahmed, Sarah (2014). The cultural politics of emotion. Edinburgh: Edinburgh University Press.

Bates, Tarsh \& Schlipalius, Megan (2013). Necessary Expandability: an exploration of nonhuman death in public. In J. Johnston, \& F. Probyn-Rapsey, Animal Death (pp. 4366.). Sydney pp.: Sydney University Press.

Bull, Jacob (2014). Between ticks \& people: Responding to nearbys and contentments . Emotion, Space and Society 12, pp.73-84.

Haraway, Donna (2008). When species meet. Vol. 224. Minneapolis : University of Minnesota Press.

Hird, Myra (2009). The origins of sociable life: evolution after science. Basingstoke: Palgrave Macmillan.

Holmberg, Tora (2011). Mortal love: Care practices in animal experimentation . Feminist Theory $12.2,147-163$.

Keller, Evelyn Fox (1983). A Feeling for the Organism: The Life and Work of Barbara McClintock. San Francisco: W.H. Freeman. 
Knudsen, Britta Timm \& Stage, Carsten (2015). Affective Methodologies: Developing Cultural Research Strategies for the Study of Affect. Basingstoke, Hampshire: Palgrave Macmillan.

Mehrabi, Tara (2016). Making Death Matter: A Feminist Technoscience Study of Alzheimer's Sciences in the Laboratory. Vol. 700. . Linköping: Linköping University Electronic Press.

Mehrabi, Tara (2018). Being intimate with flies: on affective methodologies and laboratory work. Kvinder, Køn \& Forskning 1 , 73-80.

Myers, Natasha (2015). Rendering life molecular: models, modelers, and excitable matter. Durham: Duke University Press. 